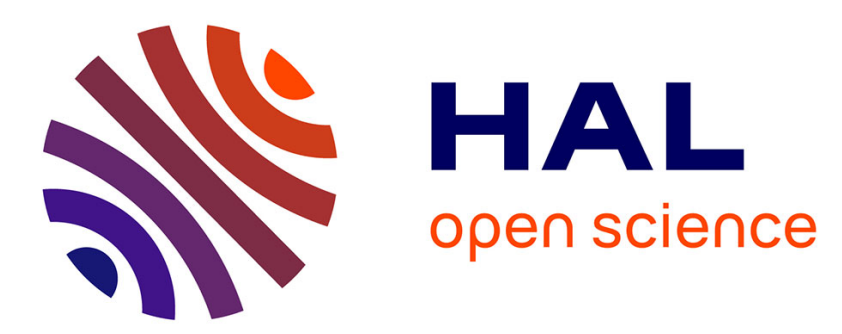

\title{
Assessing pesticide concentrations and fluxes in the stream of a small vineyard catchment. Effect of sampling frequency
}

\author{
Marion Rabiet, C. Margoum, V. Gouy, N. Carluer, Marina Coquery
}

\section{To cite this version:}

Marion Rabiet, C. Margoum, V. Gouy, N. Carluer, Marina Coquery. Assessing pesticide concentrations and fluxes in the stream of a small vineyard catchment. Effect of sampling frequency. Environmental Pollution, 2010, 158 (3), pp.737-748. 10.1016/j.envpol.2009.10.014 . hal-00504970

\section{HAL Id: hal-00504970 \\ https://hal.science/hal-00504970}

Submitted on 22 Jul 2010

HAL is a multi-disciplinary open access archive for the deposit and dissemination of scientific research documents, whether they are published or not. The documents may come from teaching and research institutions in France or abroad, or from public or private research centers.
L'archive ouverte pluridisciplinaire HAL, est destinée au dépôt et à la diffusion de documents scientifiques de niveau recherche, publiés ou non, émanant des établissements d'enseignement et de recherche français ou étrangers, des laboratoires publics ou privés. 
Assessing pesticide concentrations and fluxes in the stream of a small

4 M. Rabiet*, C. Margoum, V. Gouy, N. Carluer, M. Coquery

5

6 Cemagref, UR QELY, 3bis quai Chauveau, CP 220, F-69336 Lyon, FRANCE

7

8 *Corresponding author. Tel.:+33 (0)5 554574 84; fax: +33 (0)5 55457203 .

9 E-mail address. marion.rabiet@unilim.fr

10 Present address: Groupement de Recherche Eau Sol Environnement, University of Limoges,

11123 avenue Albert Thomas, F-87060 Limoges, France.

\section{Abstract}

13 This study reports on the occurrence and behaviour of six pesticides and one metabolite in a 14 small stream draining a vineyard catchment. Base flow and flood events were monitored in 15 order to assess the variability of pesticide concentrations according to the season and to 16 evaluate the role of sampling frequency on the evaluation of fluxes estimates. Results showed 17 that dissolved pesticide concentrations displayed a strong temporal and spatial variability. A 18 large mobilisation of pesticides was observed during floods, with total dissolved pesticide 19 fluxes per event ranging from $5.7 \cdot 10^{-3} \mathrm{~g} / \mathrm{Ha}$ to $0.34 \mathrm{~g} / \mathrm{Ha}$. These results highlight the major 20 role of floods in the transport of pesticides in this small stream which contributed to more 21 than $89 \%$ of the total load of diuron during August 2007. The evaluation of pesticide loads 22 using different sampling strategies and method calculation, showed that grab sampling largely 23 underestimated pesticide concentrations and fluxes transiting through the stream.

24

\section{Capsule}

26 This work brings new insights about the fluxes of pesticides in surface water of a vineyard 27 catchment, notably during flood events.

\section{Keywords}

31 Diuron, Flood, Fluxes, Pesticide, Surface water, Vineyard catchment 32 


\section{1. Introduction}

36 The intensive use of pesticides for crop protection against diseases led to the widespread

37 presence of these compounds in all the compartments of the environment (soil, water, air).

38 The contamination of surface waters by these biologically active chemicals is an important

39 unwanted side effect of their use. Such contaminations represent a potential risk to aquatic life

40 particularly in rivers draining agricultural areas. Numerous authors have evaluated the

41 transport of pesticides from agricultural lands to rivers (e.g., Clark and Goolsby, 2000; Du

42 Preez et al., 2005; Claver et al., 2006, Blanchoud et al., 2007). Large-scale studies on

43 pesticide losses to surface waters showed that the transfer of pesticides is largely influenced 44 by the intrinsic properties of each compound, but also by the weather conditions, the soil

45 types and land use (Kreuger, 1998; Capel et al., 2001; Riise and al., 2004). The role of 46 hydrology in non point diffuse pesticide pollution is documented, but hardly quantified.

47 Several authors emphasized the significance of rainfall-induced surface runoff as a major 48 source of pesticides in streams (Richards and Baker, 1993; Kuivila and Foe, 1995; Ng and 49 Clegg, 1997; Kreuger, 1998; Capel et al., 2001; Bach et al., 2001; Schulz, 2001a; Schulz, 50 2001b; Holvoet et al., 2007; Vryzas et al., 2009). Rapid flow processes drastically reduce the 51 time available for reactions, such as sorption or degradation, and can lead to a direct transfer 52 of pesticides towards surface waters (Müller et al., 2003). It is widely recognised that during

53 floods, fluxes of many pollutants (e.g., nutrients, metals, pesticides) can vary over several 54 orders of magnitude and may account for the majority of the annual load of pollutants in large 55 river systems (Meybeck, 2005; Zonta et al., 2005; Eyre and Pont, 2003; House and Warwick, 56 1998). Much less is known about pesticide transfer dynamics and loads in small stream 57 systems, where hydrological conditions are subject to fast and considerable variation with 58 time (Gargouma et al., 1997; Ng and Clegg, 1997; Kreuger, 1998; Louchart et al., 2004; Leu 59 et al., 2004; Domange, 2005). Surface waters draining vineyard areas are of specific concern 
60 due to the large quantities and diversity of pesticides applied and the vulnerability of 61 cultivated land (i.e., shallow soil depth, steep slopes). Indeed, several studies reported the 62 presence of pesticide residues in surface waters in vineyard areas (Lennartz et al., 1997;

63 Louchart et al., 2001; Ribolzi et al., 2002; Louchart et al., 2004; Rabiet et al., 2008, 64 Hildebrandt and al., 2008). In spite of this highlighted vulnerability of vineyard areas, very 65 few studies reported on the spatio-temporal variability of pesticide concentrations nor on the 66 evaluation of corresponding fluxes. The assessment of pesticide fluxes is essential to evaluate 67 the environmental performance of agricultural practices and to improve water quality at a 68 basin scale. In small stream, Preston et al. (1992) and Cohn (1995) showed that flux estimates 69 of nutrients or metals were often strongly biaised when water discharge varied greatly with 70 time.

71 One of the objectives of the European Water Framework Directive (WFD, European 72 Commission, 2000) is to reach a "good status" for European rivers by 2015. The 73 implementation of the WFD implies the intensification of the monitoring of contaminants, the 74 identification of the causes of degradation and the implementation of corrective actions to 75 obtain a good chemical and biological status. For this purpose, Member States have to 76 establish a comprehensive monitoring strategy to establishcontaminant exposure levels in 77 surface waters and to evaluate the water quality improvement linked to various management 78 programmes at the catchment scale. Within the WFD, operational monitoring is required for 79 the 33 priority substances; it should be performed via grab sampling 12 times per year. 80 Pesticide transfer during flood events are not specifically considered whereas many studies 81 showed their major role by mobilising great quantity of contaminants. Moreover, several 82 authors (e.g., Schleppi et al., 2006; Johnes, 2007; Horowitz, 2008) have shown for river 83 systems and also small streams that an infrequent monitoring programme, with sampling 84 performed only for a representative range of flow conditions may yield better estimates of 
85 solute loads (nutrients, sediment-associated trace elements or major elements) than a routine

86 water quality monitoring programme with sampling at fixed time intervals, regardless of flow

87 conditions The objectives of this work was on the one hand to evaluate the spatiotemporal

88 variability of pesticides concentrations and fluxes in an small-sized vineyard catchment

89 (inferior to $10 \mathrm{~km}^{2}$ ) and on the other hand to assess the outcome of different sampling

90 strategies on the estimation of pesticide fluxes. In particular, the effect of sampling frequency

91 on the evaluation of pesticide loads and concentrations using several sampling strategies was

92 estimated and discussed.

93 The Morcille catchment was selected for this study as it is a vineyard's area and its small size

$94\left(8 \mathrm{~km}^{2}\right)$ corresponds to the scale where novel agricultural practices are implemented and

95 evaluated for their environmental performance towards the protection of water quality. One

96 site of the Morcille stream was instrumented in order to monitor both flood and between-

97 flood (base flow) events during one hydrological year. We used various set of monitored data

98 (weekly or monthly grab, weekly automatic fractionated sampling) to compare concentrations

99 and fluxes obtained using these different sampling strategies..

100

\section{2. Material and methods}

\subsection{Study area}

103 The investigation site is the Morcille catchment, which has been studied for a long-time by

104 the Cemagref, french agricultural and environmental engineering research institute. It is a

105 representative catchment of the Beaujolais area for the study of the transport of pesticides 106 from agricultural parcels to surface water (Gouy and Nivon, 2007; Rabiet et al., 2008). The 107 Morcille catchment is located about $70 \mathrm{~km}$ north of the city of Lyon in France (Fig. 1). Its 108 small size $\left(8 \mathrm{~km}^{2}\right)$ allows to define a study area where transfers are more easily 109 comprehensible. The head of the basin is essentially covered by forest, whereas downstream it 
110 is mainly dedicated to vineyard with the presence of about 70 wine-growers (Gouy and

111 Nivon, 2007). The vine covers about $70 \%$ of the catchment's total area (Fig. 2). No industrial

112 activities are present on the site. The hydrology regim of the Morcille stream varies

113 considerably over the year, with instantaneous water flow ranging from $0.005 \mathrm{~m}^{3} / \mathrm{s}$ (low-water 114 mark) to more than $0.5 \mathrm{~m}^{3} / \mathrm{s}$ (during storms). It is characterised by significant hydrological

115 events (strong and fast floods). The substratum of the catchment is an altered crystalline 116 basement of mainly granite, with some rather homogeneous soils varying from sandy loam on 117 the upper slopes to more clayey soils in the bottom of the valley (Gouy and Nivon, 2007).

118 Considering the soil texture, the rather steep slopes (varying from $2 \%$ to more than $20 \%$ ) and 119 the presence of a shallow crystalline basement, it is likely that infiltration and sub-surface 120 lateral flow are major processes. Surface runoff only appears during high intensity rainstorms 121 exceeding the soil infiltration capacity. In this area, climatic, geological, topographical and 122 agricultural conditions concur to potentially create very dynamic hydrological conditions and 123 a high erosion rate. Thus, pesticide transfer to surface waters may be favoured. In vineyards, 124 herbicides are applied from the end of March to April, whereas fungicides and insecticides are 125 used from May to August. Considering both hydrologic conditions and pesticide application 126 dates, the more critical period as regards to surface water contamination extends from April to 127 the end of August.

\subsection{Water sampling}

130 A monitoring survey was performed from March 2007 to March 2008 during a complete vine

131 growing season. Three sampling sites along the Morcille stream from upstream (1-St-Joseph), 132 intermediate (2-Les Versauds) to downstream (3-St-Ennemond) were monitored in order to 133 approach the spatial variability (Fig. 1 and 2). As for the temporal variability, a sampling 134 strategy was defined so as to investigate the three sites during one year, focusing on the 
135 pesticide application periods and the following months. Hence, a more intensive monitoring, 136 with weekly grab samples, was performed from March to September 2007, which included

137 the pesticide application period; a monthly grab monitoring was done thereafter (from 138 October 2007 to March 2008).

139 In order to better identify pesticide concentration amplitude and fluxes during storm events, a 140 specific monitoring was performed at the intermediate site (2- Les Versauds) during spring 141 and summer 2007. Sampling was performed using two refrigerated automated samplers 142 (Bühler, model 4010) with a capacity of 24 polyethylene (PE) bottles. The high capacity of

143 each samplers as well as the use of two samplers allowed to minimize the risk of missing a 144 portion of the flood event. It permitted a fractionated flood sampling at a rate proportional to 145 the flow, allowing to better estimate fluxes than a time dependant sampling. Automatic 146 sampling parameterization was designed using knowledge and experience from the previous 147 two years of flow measurements (2005 and 2006).

148 In addition, in order to compare various sampling strategies to assess pesticide fluxes and 149 mean concentrations in this stream, a weekly composite sampling was performed in July and 150 August 2007 with an additional refrigerated automatic sampler (Bamo, model Aquacell) 151 equipped with a single PE bottle of $10 \mathrm{~L}$. This sampler was also programmed to be 152 proportional to the flow. Thus five sampling methods were compared at site 2: grab sampling 153 (weekly, bi-monthly or monthly), automatic fractionated sampling during storms and 154 automatic weekly composite sampling.

155 In parallel, the water depth was continuously recorded at site 2 with a pressure sensor and 156 converted into water flow values using a sampling-site specific calibration function. Rainfall 157 was measured using two raingauges (i.e. tipping bucket system) located upstream and in the 158 middle of the Morcille catchment (Fig. 2). Data obtained with each gauge were similar and 
159 didn't show any significative spatial variability of rainfall. In this study, we reported only the 160 data obtained with the closest raingauge to site 2.

161

\subsection{Pesticides analysis}

\section{$\underline{\text { Pesticides selection }}$}

164 It was not intended to analyse all the pesticides present in surface water of the Morcille 165 stream, but rather to select a range of compounds widely used in vineyard catchment and with 166 various physico-chemical properties. Pesticides were selected among a list resulting from 167 previous screening analysis in surface water at the same site (Gouy and Nivon, 2007, Rabiet 168 et al., 2008). Six pesticides and a main metabolite were chosen from different families of 169 herbicides and fungicides currently used for vineyard treatments: azoxystrobin (AZS), 170 carbendazim (CBZ), dimetomorph (DMM), procymidone (PCM), tebuconazole (TBZ),

171 diuron (DIU) and one of its metabolites: 3-(3,4-dichlorophenyl)-1-methyl urea (DCPMU).

172 Their main physico-chemical properties are presented in Table 1. Diuron, an herbicide largely

173 used on vineyard, is included in the list of the priority substances of the WFD (European 174 Commission, 2000, 2008). Insecticides, although widely used in vineyard to protect crop 175 again pest, were not monitored in this study since occurence as well as concentrations were 176 found to be negligible in the water bodies of the Morcille watershed (Gouy and Nivon, 2007).

\section{$178 \underline{\text { Chemicals }}$}

179 Pure pesticides used for standard solutions or quality controls were of analytical grade and 180 supplied by Cluzeau Info Labo (Sainte Foy la Grande, France) or Sigma Aldrich (Saint 181 Quentin Fallavier, France). Organic solvents used were pesticide or HPLC grade (SDS, 182 Peypin, France). 
183 The individual stock solutions were prepared in acetone at a concentration of $100 \mathrm{mg} / \mathrm{L}$ and

184 stored at $4^{\circ} \mathrm{C}$. These stock solutions were stable for 2 months. Standard working solutions at

185 various concentrations were prepared weekly by appropriate dilutions of the stock solutions in 186 ultrapure water/ acetonitrile $(80 / 20, \mathrm{~V} / \mathrm{V})$.

187

\section{Sample pre-treatment}

189 Except for weekly composite sampling, samples were collected within a maximum of $24 \mathrm{~h}$

190 after sampling and returned to the laboratory for immediate filtration. Water samples were

191 filtered on glass fiber filters $(0.7 \mu \mathrm{m}, \varnothing=47 \mathrm{~mm}$, GF-F Whatman, Sodipro, Echirolles, 192 France). Extraction was carried out on solid phase extraction (SPE) cartridges (Oasis HLB, 60 $193 \mathrm{mg}, 3 \mathrm{~mL}$, Waters, France) after spiking with linuron used as analytical control standard. Ten $194 \mu \mathrm{L}$ of internal standard control (deutered diuron) were added to the final extract of $240 \mu \mathrm{L}$ 195 water/acetonitrile $(80 / 20, \mathrm{~V} / \mathrm{V})$. The concentration factor was about 1000 . The organic 196 extracts and corresponding calibration standards were kept at $-20^{\circ} \mathrm{C}$ prior to analysis.

197

$198 \underline{\text { Analysis }}$

199 Water sample extracts were quantified by ESI-LC-MSMS (LC 1100 Agilent, API 4000 200 Applied Biosystems, Courtaboeuf, France). The compounds were separated on a $250 \times 2 \mathrm{~mm}$ 201 Purospher Star RP-18 column (Merck). The mobile phase was water/acetonitrile gradient at $2020.3 \mathrm{~mL} / \mathrm{min}$. The limit of quantification (LQ) ranged between 0.020 and $0.080 \mu \mathrm{g} / \mathrm{L}$ according 203 to the pesticides, and recoveries varied from 80 to $107 \%$, depending on the concentration 204 level and the compound (Margoum et al., 2007). All the concentration results presented in this 205 study were then corrected with the corresponding recovery rate. 


\section{2.4. Quality assurance}

209 Possible losses of compounds by sorption or degradation during sample collection, storage

210 and transport was evaluated in two separate laboratory studies. First, pesticide stability during

211 storage in PE bottles was assessed. Mineral Evian water (3 replicates) was spiked with the

212 studied pesticides $(5 \mu \mathrm{g} / \mathrm{L})$ and then stored in the same conditions as during monitoring (at $2134^{\circ} \mathrm{C}$ in darkness). Pesticides analyses were performed at time $0,1 \mathrm{~h}, 24 \mathrm{~h}, 48 \mathrm{~h}$ and 7 days in 214 order to simulate different time of storage inside the automatic samplers. Results are 215 presented in Figure 3. Diuron is the most stable compound in PE bottle with losses below 3\%, 216 even over a seven days period. For dimetomorph and DCPMU, losses are below 10\% during 217 storage. It is also the case for procymidone over a 2 days period. However, over a seven days 218 period, procymidone showed a significant decrease of concentration, with about $40 \%$ of 219 losses. This behaviour could be due to its relatively high Koc (Table 1). Despite their 220 respectively low half life and high Koc, azoxystrobin and tebuconazol showed a good 221 stability, with maximum losses reaching a maximum of $15 \%$ over 7 days. In conclusion, 222 stability of all compounds is satisfying over 7 days, expect for procymidone; thus average 223 weekly concentrations of procymidone might be somewhat underestimated.

224 In the second study, spiked and unspiked mineral water (Evian) were run through the 225 automatic sampler (i.e., passing through the tubes and collected in the receiving bottles of the 226 sampling equipment) in order to verify the potential loss of pesticides and the absence of 227 contamination, respectively. No significant adsorption or release of pesticides was observed 228 (i.e., the relative difference of pesticide concentrations before and after the sampler was 229 below 5\%).

230 Field and analytical blanks (using ultrapure water in PE bottles) were also performed for each 231 monitoring campaign. 


\section{2.5. Flux calculation}

234 Pesticide fluxes were estimated at site 2 over various periods and using different data and 235 calculation methods.

236 The weekly load of pesticides (WL) was calculated for the March-September period, using 237 the manual weekly sampling data, by multiplying the average weekly stream flow by the total 238 pesticide concentration (i.e., sum of the concentrations of the 8 studied pesticides) measured 239 on grab samples as follows:

$240 \mathrm{WL}(\mu \mathrm{g})=\mathrm{Q} \times \mathrm{C}_{\mathrm{i}} \times \mathrm{t}_{\mathrm{i}} \quad$ equation (1)

241 where $Q$ is the average weekly stream flow during the considered period $t_{i}(L / s) ; C_{i}$ is the 242 concentration of total pesticides analysed in grab samples collected once a week $(\mu \mathrm{g} / \mathrm{L})$; and $t_{i}$ 243 is the considered time period (s) (seven days surrounding the sampling day).

244 For the monthly monitoring, over the October-March period, monthly pesticide fluxes were 245 estimated in the same way by multiplying the average monthly stream flow by the total 246 pesticide concentration measured on the samples collected manually once a month. 247 Concentrations below the LQ were set to half of the LQ for these calculation. Compounds not 248 detected were set to 0 .

249 The total pesticide load during a flood (FL) was calculated using the following equation:

$250 \mathrm{FL}(\mu \mathrm{g})=\Sigma \mathrm{q}_{\mathrm{i}} \times \overline{C_{i}} \times \mathrm{t}_{\mathrm{i}} \quad$ equation (2)

251 with qi, the instant flow at the time $\mathrm{i}(\mathrm{L} / \mathrm{s}) ; \overline{C_{i}}$, the concentration value linearly interpolated 252 between both nearest measured pesticide concentrations $(\mu \mathrm{g} / \mathrm{L})$; and $\mathrm{t}_{\mathrm{i}}$, the time interval 253 between the flow measurements (s). This time varied from several seconds to minutes. 


\section{3. Results and discussion}

259

2603.1 Hydrological context

261 Daily rainfall $(\mathrm{mm})$ and water flow (L/s) of the Morcille stream at site 2 for the study period 262 (from 01/03/2007 to 31/03/2008) are presented in Figure 4. Total annual precipitation during 263 year 2007 was about $909 \mathrm{~mm}$. This value is not significantly different from the average 264 annual precipitation during the past fifteen years $(860 \mathrm{~mm})$. However, summer was 265 particularly wet in 2007, with a total precipitation of $426 \mathrm{~mm}$ from May to August (Fig. 4), 266 compared to $290 \mathrm{~mm}$ in average (for the past fifteen years) (Meteo France). Especially, the 267 months of June and August were particularly wet (125 and $101 \mathrm{~mm}$ respectively, versus an 268 average of 67 and $78 \mathrm{~mm}$, respectively). This specific context could contribute to increase 269 surface water contamination by pesticide: on the one hand, a higher occurrence of storms in 270 summer is favorable to surface runoff contributing to mobilise more pesticides, and, on the 271 other hand, wet conditions often lead farmers to use more pesticides than a normal year, 272 because of a higher risk of crop disease.

273

274 3.2. Grab monitoring of pesticide concentrations along the Morcille stream

275 Dissolved herbicides and fungicides concentrations measured from grab weekly and monthly 276 samples along the Morcille stream from 6 March 2007 to 18 March 2008 are reported in 277 Figure 5.

278 The presence of pesticides was demonstrated throughout the investigation period with a large 279 seasonal variation, corresponding to the pesticide application calendar. Indeed, total pesticide 280 concentrations range from below the LQ to $16.4 \mu \mathrm{g} / \mathrm{L}$. Diuron and DCPMU concentrations 281 ranged from below the limit of quantification (LQ) to $13.3 \mu \mathrm{g} / \mathrm{L}$ (Fig. 5a). Concentrations 282 were below $0.2 \mu \mathrm{g} / \mathrm{L}$ in March 2007 and 2008, corresponding to a residual background linked 283 to previous vineyard treatments. DIU and DCPMU concentrations increased in the stream at 
284 the beginning of April 2007, according to the onset of herbicide spreading on vineyard. The 285 highest herbicide concentration was observed in May and June and at the beginning of July.

286 Total fungicide concentrations were very low in March and April 2007 (below $0.3 \mu \mathrm{g} / \mathrm{L}$ ). In

287 May, fungicide concentrations increased slightly with values ranging between 0.3 and 0.9 $288 \mu \mathrm{g} / \mathrm{L}$ at the downstream site. Starting in June, fungicide concentrations rose sharply. The 289 maximum concentration was observed in July with $8.3 \mu \mathrm{g} / \mathrm{L}$ at site 3 (Fig. 5b).

290 Herbicide as well as fungicide concentrations decreased in August, but remained at a 291 detectable level during all year round: this was especially the case for diuron, mainly applied 292 in late winter but also locally until early summer due to the wet conditions. Thus, surface 293 water contamination by pesticides largely overstepped the application period, as shown by the 294 high pesticide concentrations still present in January (up to $2.0 \mu \mathrm{g} / \mathrm{L}$ at site 3 ).

295 Besides seasonal variations, we observed a large variability of pesticide concentrations with 296 time, over very short periods. For instance, between the 30 May 2007 and the 05 June 2007, 297 diuron and metabolite concentrations at site 3 increase from 0.3 to $13.3 \mu \mathrm{g} / \mathrm{L}$. This high 298 reactivity may be related to the rapid pesticide transfer via runoff due to storm events, which 299 can mobilise a large and variable quantity of pesticides. Indeed, this period of the year was 300 marked by large rainfall, with about $55 \mathrm{~mm}$ during one week (cf. Fig. 4); this led to a shorter 301 delay between pesticide application and precipitation and favouring the direct transfer to 302 surface water.

303 We present in Figure 6 the relationship observed between total dissolved pesticide 304 concentrations and water flow during grab monitoring at site 2 . The positive linear regression 305 is statistically significant $\left(\mathrm{r}^{2}=0.78 ; \mathrm{P}<0.0001\right)$. The low pesticide concentration for high flux 306 corresponds to a sample collected during a storm event at the end of summer, thus at the end 307 of the application period. 
308 We noted that pesticide concentrations generally increased with water flow during the 309 application period and the following months as well, when it is likely that pesticide input to 310 soil and their availability in soil is still significant. This underlined the major role of

311 hydrological conditions on the mobilisation of pollutant. As for pesticide occurrence during

312 base flow, it is assumed that it can be related to the slow processes of water movement

313 through the soil matrix such as subsurface runoff, drainage and exchanges with shallow water 314 table (Müller et al., 2003).

315 On a spatial point of view, we measured a large increase of pesticide concentrations from 316 upstream to downstream, which is coherent with the increasing proportion of vineyard surface 317 downstream (Fig. 2). Indeed, at the upstream reference site (site 1), only diuron and its 318 metabolite, as well as dimetomorph and procymidone were quantified and only twice at low 319 levels (from the LQ up to $2 \mu \mathrm{g} / \mathrm{L}$ ). This reflects the small impact of vineyard treatment at the 320 upstream site, whereas at the outlet, pesticides were systematically quantified with a mean 321 concentration of total pesticides of $3.2 \pm 4.0 \mu \mathrm{g} / \mathrm{L}$ at site 3 .

322 The distribution between the different compounds/molecules at site 2 is reported in Figure 7. 323 Diuron predominated, with concentrations ranging from $0.01 \mu \mathrm{g} / \mathrm{L}$ to $7.5 \mu \mathrm{g} / \mathrm{L}$. Thus, the 324 average concentration of diuron $(1.2 \pm 2.0 \mu \mathrm{g} / \mathrm{L})$ largely exceeded the European 325 environmental quality standard (EQS) of $0.2 \mu \mathrm{g} / \mathrm{L}$ expressed as annual average value 326 (European Commission, 2008). Moreover, at site 3, the downstream site, more than one third 327 of the samples exhibited diuron concentrations higher than the maximum allowable 328 concentration (MAC) of $1.8 \mu \mathrm{g} / \mathrm{L}$ (European Commission, 2008). These results reflect the 329 strong impact of diuron used in vineyard on the surface water quality all along the year. 330 Moreover, DCPMU, a main metabolite of diuron, was systematically quantified with 331 concentrations ranging between 0.01 and $0.5 \mu \mathrm{g} / \mathrm{L}$ at site 2 . At site 3 , DCPMU concentration 332 ranged between 0.2 and $1.4 \mu \mathrm{g} / \mathrm{L}$, with a mean concentration of $0.3 \pm 0.3 \mu \mathrm{g} / \mathrm{L}$. Dimetomorph 
333 and procymidone, two fungicids commonly utilized on vines, were mostly quantified during 334 the month of July, with concentrations reaching up to 3.4 and $1.3 \mu \mathrm{g} / \mathrm{L}$ respectively at the 335 intermediate site, reflecting their application period on the basin. Tebuconazol was detected 336 all along the application period at site 2 with concentration ranging between 0.02 and 1.9 $337 \mu \mathrm{g} / \mathrm{L}$, corresponding to an average concentration of $0.2 \pm 0.3 \mu \mathrm{g} / \mathrm{L}$. Carbendazim and 338 azoxystrobin were less often quantified in the stream, with mean concentrations of $0.1 \pm 0.2$ $339 \mu \mathrm{g} / \mathrm{L}$ and $0.08 \pm 0.09 \mu \mathrm{g} / \mathrm{L}$, respectively at the downstream site (site 3).

340 The weekly load of total dissolved pesticides at site 2, estimated from equation (1), ranged 341 between $3.3 \mathrm{~g}$ and $337 \mathrm{~g}$ over the study period. This lead to an annual load of pesticides of $3422200 \mathrm{~g}$ then $12.5 \mathrm{~g} / \mathrm{Ha}$ taking into account the vine surface drained at site 2 (175 Ha). More 343 than $50 \%$ of this amount (1088 g) was transferred during June and July only, with 623 and $344465 \mathrm{~g}$, respectively. Noteworthy, diuron and its metabolite represented 68\% (1502 g) of the 345 annual total load. It represented about $8.6 \mathrm{~g}$ of diuron and metabolite per hectare. Considering 346 the recommended amount of diuron to be applied per hectare and per year on this type of 347 culture (i.e., $1500 \mathrm{~g} / \mathrm{Ha}$, Couteux and Lejeune, 2007), about $0.57 \%$ of the total amount of 348 applied diuron reached the Morcille stream. Noteworthy, the load of exported diuron should 349 probably decrease in the future, as its use is no longer authorized. This value is in agreement 350 with measured pesticide losses to surface water reported by other authors (for cereal cultures), 351 ranging from 0.01 to $0.5 \%$ of application amounts (Brown et al., 1995; Kreuger, 1998). In 352 fact, our calculation was based on pesticide concentrations measured in weekly grab samples, 353 which mainly corresponded to base-flow conditions; thus it did not take into account the 354 majority of high-flow events, likely to contribute to annual pesticide load transiting through 355 the Morcille stream. We might consider that the estimation of $0.57 \%$ of diuron losses 356 probably largely underestimates the actual quantity of diuron exported from vine parcels to 357 the stream. However, in a Mediterranean vineyard catchment, Louchart et al. (2001) 
358 estimated to $0.52 \%$ the total seasonal losses for diuron, including losses by storm flow and 359 baseflow. This lower value compared to our result is probably due to different caracteristics 360 of the watershed studied, in particular the slope; alternatively it might result from differences 361 in the monitoring and calculation methods. In this study, base flow only contributed to $4 \%$ of 362 total losses.

363

364 3.3. Storm events monitoring during spring and summer 2007

365 We monitored 8 floods from April to September 2007. Among them, 5 floods were fully 366 monitored and 3 floods could only be sampled in the region of the water flow peak. Sampled 367 flood events were characterised by a maximum water flow ranging between 0.03 and 0.78 $368 \mathrm{~m}^{3} / \mathrm{s}$ and a duration lasting between 2 and 11 hours. These characteristics are typical of most 369 events taking place in the Morcille catchment (Taillandier, 2008).

370 The maximum pesticide concentration recorded during each flood event, as well as the total

371 flux are presented in Table 3 for each monitored compound. Figure 8 presents the distribution 372 of diuron concentrations during the 8 monitored floods, as it is the main pesticide quantified 373 during the study period.

374 As expected, we observe a large mobilisation of diuron in the stream during the high flow 375 events. Concentrations rose rapidly, then usually hit the highest point almost at the same time 376 as water flow peak (Fig. 8). However, a lag time (ranging between few minutes and more than 3771 hour according to the event) was sometimes observed before or after the maximal pesticide 378 concentration, in comparison with the water flow peak. Concentrations declined thereafter. 379 Maximum pesticide concentration during the 8 monitored floods ranged from $4.8 \mu \mathrm{g} / \mathrm{L}(27$ 380 September 2007, outside the spreading period) to $140 \mu \mathrm{g} / \mathrm{L}$ (01-02 July 2007, considered as 381 exceptional) with an average value of $26.7 \pm 42.8 \mu \mathrm{g} / \mathrm{L}$. The $01-02$ July storm event was 382 characterized by very high concentrations of all monitored pesticides (about 10 times higher 
383 than for other flood events). Thus, we considered this event as exceptional, probably due to 384 the occurrence of the flood just after pesticides application.. Some authors (Louchart et al., 385 2001; Leu et al., 2004; Phillips and Bode, 2004) have indeed shown that the major pesticide 386 losses occurred during the first rain event after application. Excluding this exceptional event, 387 as well as the event taking place out of spreading period (end of September), maximum 388 concentrations during floods were between 7.3 and $21.1 \mu \mathrm{g} / \mathrm{L}$, with an average value of 12.7

$389 \pm 4.3 \mu \mathrm{g} / \mathrm{L}$. Among all the monitored pesticides, diuron was the most mobilised compound 390 during flood. Its contribution reached up to $76 \%$ of the total pesticide load transiting during

391 flood. Maximum diuron concentrations observed during the flood events were always higher 392 than the MAC (European Commission, 2008).

393 Depending on the flood (and excluding the extreme event of 01-02 July 2007), pesticide 394 maximum pesticide concentrations varied by a factor of 3 only, whereas peak water flows 395 varied by a factor of up to 30 . Thus, maximum pesticide concentrations did not seem to be a 396 simple function of water flow and it is likely that other processes interfered, such as pesticide 397 availability via runoff.

398 During floods, the total dissolved pesticide fluxes ranged from 1.0 to $60 \mathrm{~g}$. When occurring 399 immediately after application, even a flood of moderate intensity could in fact deliver to the 400 stream a significant load of pesticides in a very short period.

401

402 3.4. Significance of the sampling strategy on the estimation of diuron fluxes and 403 average concentration

\section{Flux estimation}

405 In order to assess the effect of the sampling strategy on the estimation of diuron fluxes and 406 average concentration, we used different methods and various set of data monitored at site 2 407 in August 2007. This specific month was chosen for this exercise since a majority of the 
408 storm events during this period could be collected (Fig. 9). Besides, pesticide concentrations 409 during this period were still very significant.

410 The monthly diuron flux was estimated using weekly, bimonthly or monthly simulated grab 411 monitoring by choosing either the first, second, third or fourth weekly sample as the reference 412 concentration for the calculation; or alternatively, by using only 1, 2 or 4 weekly data. In 413 addition, diuron monthly flux was calculated using the weekly average composite sample 414 concentrations. Finally, diuron monthly flux was estimated for either base flow only, using 415 grab samples collected during base flow conditions; or storm flow conditions only, using 416 automated sampling performed during floods. For the floods that could not be monitored 417 during this period, we estimated the corresponding diuron fluxes using an empiric linear 418 model derived from observed data. Indeed, excluding the extreme event of 01-02 July 2007, a 419 linear regression $\left(r^{2}=0.91\right)$ was obtained between diuron fluxes during flood events and the 420 total volume of water conveyed during the event. Thus, diuron flux during a flood could be 421 estimated with the following equation:

$$
\text { Diuron flux }(\mathrm{g})=\left[\text { Water volume }\left(\mathrm{m}^{3}\right) \times 3.6 .10^{-3}\right]-0.1
$$

423 Although only 7 data points were available to derive this relationship (cf. Fig. 10), it allowed 424 to estimate with less than $30 \%$ of bias diuron load during a flood event taking place during the 425 considered period (Table 4). Due to pesticide decay with time and to the limited range of 426 water flow values used to build this equation, the validity of this equation is clearly limited to 427 the study period and it would be incorrect to use it in another context and purpose.

428 Results are presented in Figure 11. According to the method used, diuron monthly fluxes 429 ranged from 4.7 to $73.9 \mathrm{~g}$. The highest value corresponded to the calculation using the weekly 430 composite sampling results, which was considered as the most accurate evaluation. Hence, 431 this value was used thereafter to estimate the bias due to grab sampling. Monthly diuron 432 fluxes, estimated from grab monitoring (weekly, bimonthly or monthly) varied between 4.7 
433 and $41.2 \mathrm{~g}$, which is significantly lower than the "most realistic" flux value (73.9 g). Even the 434 grab weekly surveys underestimated pesticide flux by a factor of about 5 at most. As a matter 435 of fact, in August 2007 around $89 \%$ of the diuron load were transported during floods, which 436 in total lasted for less than 5 days (i.e., $15 \%$ of the time). These results are similar to those of 437 Chen et al. (2005) and Louchart et al. (2001) showing that floods contributed to $90 \%$ and $84 \%$ 438 (at the field scale) respectively, of the total load (for flood season and annual time scale 439 respectively) of pesticides. This observation shows the major role of storm events in the 440 mobilisation of pesticides. Pesticide losses during baseflow appeared to be of minor 441 importance in comparison with losses during storm flow. A grab monitoring could take into 442 account only partially at best the rapid pesticide transfers. Thus, it results in non443 representative average concentrations and loads, and in a higher probability of mis444 interpretation of the water quality status, as showed as well by Holvoet et al. (2007). A 445 combined monitoring survey during base flow and storm flow allowed to evaluate the 446 temporal variability in pesticide concentrations. Moreover, the total diuron flux could be 447 derived with a good precision: indeed our estimation reached $53.6 \mathrm{~g}$, that is $72.5 \%$ of the 448 "reference" value (Fig. 11). However, it corresponded to a high technical, material and 449 analytical cost investment.

450

451 Estimation of annual average and monthly average diuron concentration

452 The annual average diuron concentration ranged between $1.2 \pm 2.0 \mu \mathrm{g} / \mathrm{L}$ using weekly 453 monitoring (4 samples per month during the application period, then one sample per month, 454 that is $n=35$ samples), and 1.4 to $1.6 \pm 2.5 \mu \mathrm{g} / \mathrm{L}$ with monthly monitoring $(\mathrm{n}=12)$ (Table 3$)$. 455 Thus, both sampling methods lead to comparable average and standard deviation results, as 456 previously showed for flux estimates. Moreover, monthly average diuron concentrations were 457 calculated for August, using the data obtained through the different monitoring strategies 
458 (grab and automatic weekly composite samples). Results showed that average diuron

459 concentration ranged from $0.4 \pm 0.4 \mu \mathrm{g} / \mathrm{L}$ using weekly grab sampling data $(\mathrm{n}=4)$ to $1.6 \pm 1.2$

$460 \mu \mathrm{g} / \mathrm{L}$ using average composite sampling $(\mathrm{n}=4)$. Combining monitoring during base flow and

461 storm flow, (using the estimated diuron flux, 53.6 g, cf. Fig. 11, and total water volumes

462 conveyed during the month, $42300 \mathrm{~m}^{3}$ ) lead to an average diuron concentration of $1.3 \mu \mathrm{g} / \mathrm{L}$ in

463 August, in good agreement with the average concentration obtained using the composite

464 weekly sampling. Obviously, grab monitoring, even at a weekly rate, underestimated the

465 average concentration in the Morcille stream.

466

\section{4. Conclusion}

468 The present study reported the great spatial and temporal variability of some herbicide and 469 fungicide concentrations monitored during one year in an agricultural catchment devoted to 470 vineyard. Their occurrence was closely related to the application calendar and the

471 hydrological conditions. Pesticide concentrations were higher during the application season, 472 with maximum concentrations occurring during June and July. Concentrations largely 473 exceeded water quality criteria for the protection of aquatic life. Pesticides were measured in 474 surface water for several months after the application and in the case of diuron, throughout 475 the year. It pointed out their potential to persist in soils and shallow groundwater. The loss of 476 diuron in the catchment outflow was evaluated at $0.57 \%$ of the applied amount, which is in 477 agreement with literature data. However, as shown by our study on the effect of sampling 478 strategy, this value is certainly largely underestimated due to grab sampling. Our study of 479 pesticide behaviour during floods showed the major role of hydrological conditions in the 480 transport of pesticides. Indeed, floods contributed to more than $89 \%$ of the total load of diuron 481 transiting through the stream during August 2007. These results provided further evidence 482 that floods are the dominant pathways for the transport of pesticides in a small agricultural 
483 stream characterized by shallow soils and preponderant surface flow pathways. Using 484 comprehensive data obtained in August, we showed that the estimated diuron fluxes and 485 average concentrations were comparable using either weekly composite sampling 486 (proportional to the flow), or with a combined grab sampling during base flow and automated 487 sampling during floods.

488 A major conclusion of this study was that grab monitoring of surface water is not adapted for 489 an accurate assessment of the contaminant exposure level, especially in dynamic hydro490 systems such as the Morcille stream, where it largely underestimates the pesticides 491 concentration and fluxes. These observations have important consequences for the monitoring 492 requirements of pesticides, in the view of the implementation of the WFD.

493

\section{Acknowledgments}

495 This study was partly financed by the French regional programmes (Rhône-Alpes region496 LTER "Zone atelier bassin du Rhône" and Cluster Environment) and the national research 497 programmes ANR-EcoGER (Papier) and EC2O (Padyma). We would like to thank N. Ball 498 and B. Motte for technical field assistance and C. Guillemain for analytical optimization and 499 analyses of pesticides. Thanks are due to A. Albinet for helpful correction.

500

\section{References}

502 AFSSA, Direction du végétal et de l'environnement, AGRITOX - Base de données sur les 503 substances actives phytopharmaceutiques. http://www.dive.afssa.fr/agritox/index.php 504 (October 2008, online).

505 Bach, M., Huber, A., Frede, H.G., 2001. Input pathways and river load of pesticides in 506 Germany - a national scale modeling assessment.Water Science and Technology 43, 261-268. 
507 Blanchoud, H., Moreau-Guigon, E., Farrugia, F., Chevreuil, M., Mouchel, J.M., 2007.

508 Contribution by urban and agricultural pesticide uses to water contamination at the scale of 509 the Marne watershed. Science of the Total Environment 375, 168-179.

510 Brown, C.D., Hodgkinson, R.A., Rose, D.A., Syers, J.K., Wilcockson, S.J, 1995. Movement

511 of pesticides to surface waters from a heavy clay soil. Pesticide Science 43, 131-140.

512 Capel, P.D., Larson, S.J., Winterstein, T.A., 2001. The behaviour of 39 pesticides in surface 513 waters as a function of scale. Hydrological Processes 15, 1251-1269.

514 Chen, B., Huang, G., Li, Y., Zang, B., Huang, Y., 2005. Pesticide-loss simulation and health 515 risk assessment during the flood season in watershed systems. Water International 30, 88-98.

516 Claver, A., Ormad, P., Rodriguez, L., Ovelleiro, J.L., 2006. Study of the presence of 517 pesticides in surface waters in the Ebro river basin (Spain). Chemosphere 64(9), 1437-1443.

518 Clark, G.M., Goolsby, D.A., 2000. Occurrence and load of selected herbicides and 519 metabolites in the lower Mississippi River. Science of the Total Environment 248, 101-113.

520 Cohn, T.A., 1995. Recent advances in statistical methods for the estimation of sediment and 521 nutrient transport in rivers. Review of Geophysical Supplement, 1117-1123.

522 Couteux, A., Lejeune, V., 2007. Index phytosanitaire Acta, forty third ed., Acta, Paris.

523 Domange, N., 2005. Etude des transferts de produits phytosanitaires à l'échelle de la parcelle 524 et du bassin versant viticole (Rouffach, Haut-Rhin). Thèse de doctorat, Université Louis 525 Pasteur, Strasbourg 1, 327 pp.

526 Du Preez, L.H., Jansen van Rensburg, P.J., Jooste, A.M., Carr, J.A., Giesy, J.P., Gross, T.S., 527 Kendall, R.J., Smith, E.E., Van Der Kraak, G., Solomon, K.R., 2005. Seasonal exposures to 528 triazine and other pesticides in surface waters in the western Highveld corn-production region 529 in South Africa. Environmental Pollution 135, 131-141. 
530 European Commission, 2000. Directive 2000/60/EC of the European Parliament and of the

531 Council of 23 October 2000 establishing a framework for community action in the field of 532 water policy, Official J European Union, L327, pp. 1-72.

533 European Commission, 2008. Common Position (EC) No 3 for a Directive of the European 534 Parliament and the Council on environmental quality standards in the field of water policy 535 and amending directives 82/176/CEE, 83/513/CEE, 84/156/CEE, 84/491/CEE, 86/280/CEE 536 and 2000/60/CE. Official J European Union 18-03-2008;C71/E1.

537 Eyre, B.D., Pont, D., 2003. Intra- and inter-annual variability in the different forms of diffuse 538 nitrogen and phosphorus delivered to seven sub-tropical east Australian estuaries. Estuarine 539 Coastal Shelf Science 57, 137-148.

540 Gargouma, M., Blanchard, M., Chesterikoff, A., Ansart, P., Chevreuil, M., 1997. Seasonal 541 transport of herbicides (triazines and phenylureas) in a small stream draining an agricultural 542 basin : Melarchez (France). Water research 31, 1489-1503.

543 Gouy, V., Nivon, C., 2007. Caractérisation et suivi de la qualité des eaux sur le bassin versant 544 de la Morcille sur la période 2001-2006. Rapport d'étude Cemagref-Chambre d'agriculture du 545 Rhône,81 pp.

546 Hildebrandt, A., Guillamon, M., Lacorte, S., Tauler, R., Barcelo, D., 2008. Impact of 547 pesticides used in agriculture and vineyards to surface and groundwater quality (North Spain). 548 Water Research 42, 3315-3326.

549 Holvoet, K.M.A., Seuntjens, P., Vanrolleghem, P.A., 2007. Monitoring and modeling 550 pesticide fate in surface waters at the catchment scale. Ecological Modelling 209, 53-64.

551 Horowitz, A.J., 2008. Determining annual suspended sediment and sediment-associated trace 552 element and nutrient fluxes. Science of the Total Environment 400, 315-343. 
553 House, W.A., Warwick, M.S., 1998. Intensive measurements of nutrient dynamics in the 554 River Swale. Science of the Total Environment 210-211, 111-137.

555 Johnes, P.J., 2007. Uncertainties in annual riverine phosphorus load estimation: impact of 556 load estimation methodology, sampling frequency, baseflow index and catchment population 557 density. Journal of Hydrology 332, 241-258.

558 Kreuger, J., 1998. Pesticides in stream water within an agricultural catchment in southern 559 Sweden, 1990-1996. Science of the Total Environment 216, 227-251.

560 Kuivila, K.M., Foe, C.G., 1995. Concentration, transport and biological effects of dormant 561 spray pesticides in the San Francisco Estuary, California. Environmental Toxicology and 562 Chemistry 14, 1141-50.

563 Lennartz, B., Louchart, P., Andrieux, P., Voltz, M., 1997. Diuron and simazine losses to 564 runoff water in Mediterranean vineyards. Journal of Environmental Quality 26, 1493-1502.

565 Leu, C., Singer, H., Stamm, C., Müller, S.R., Schwarzenbach, R.P., 2004. Silmutaneous 566 assessment of sources, processes and factors influencing herbicides losses to surface waters in 567 a small agricultural catchment. Environmental Science and Technology 38, 3827-3834.

568 Louchart, X., Voltz, M., Andrieux, P., Moussa, R., 2001. Herbicide transport to surface 569 waters at field and watershed scales in a Mediterranean vineyard area. Journal of 570 Environmental Quality 30, 982-991.

571 Louchart, X., Voltz, M., Coulouma, G., Andrieux, P., 2004. Oryzalin fate and transport in 572 runoff water in Mediterranean vineyards. Chemosphere 57, 921-930.

573 Margoum, C., Guillemain, C., Rabiet, M., Gouy, V., Coquery, M., 2007. Dissipation of 574 pesticides in surface water and biofilms in a small agricultural catchment: development of a 575 methodology for studying environmental impact of pesticides. Proceedings XIII Symposium 
576 Pesticide Chemistry, Environmental Fate and Human Health, 3-6 September 2007, Piacenza, 577 Italy.

578 Meybeck, M., 2005. Looking for water quality. Hydrological Processes 19, 331-338.

579 Müller, K., Deurer, M., Hartmann, H., Bach, M., Spiteller, M., Frede, H.G., 2003.

580 Hydrological characterisation of pesticide loads using hydrograph separation at different 581 scales in a Gerlan catchment. Journal of Hydrology 273, 1-17.

$582 \mathrm{Ng}, \mathrm{H} . Y . F .$, Clegg, S.B., 1997. Atrazine and metolachlor losses in runoff events from an 583 agricultural watershed the importance of runoff components. Science of the Total 584 Environment 193, 215-228.

585 Phillips, P. J., Bode, R. W., 2004. Pesticides in surface water runoff on souh-eastern New 586 York State, USA: seasonal and stormflow effects on concentrations. Pest Management 587 Science 60, 531-543.

588 Preston, S.D., Bierman, V.J., Silliman, S.E., 1992. Impact of flow variability on error in 589 estimation of tributary mass loads. Journal of Environmental Engineering ASCE 118, 402590419.

591 Rabiet, M., Margoum, C., Gouy, V., Carluer, N., Coquery, M., 2008. Transfert des pesticides 592 et métaux dans un petit bassin versant viticole - Étude préliminaire de l'influence des 593 conditions hydrologiques sur le transport de ces contaminants, Ingénierie EAT, Special issue 594 «Azote, phosphore et pesticides: Stratégies et perspectives de réduction des Flux », 65-75.

595 Ribolzi, O., Valles, V., Gomez, L., Voltz, M., 2002. Speciation and origin of particulate 596 copper in runoff water from a Mediterranean vineyard catchment. Environmental Pollution $597117,261-271$.

598 Richards, R.P., Baker, D.B., 1993. Pesticide concentration patterns in agricultural drainage 599 networks in the Lake Erie basin. Environmental Toxicology and Chemistry 12, 13-26. 
600 Riise, G., Lundekvam, H., Wu, Q.L., Haugen, L.E., Mulder, J., 2004. Loss of pesticides from 601 agricultural fields in SE Norway-runoff through surface and drainage water. Environmental 602 Geochemistry and Health 26, 269-276.

603 Schleppi, P., Waldner, P.A.., Stähli, M., 2006. Errors of flux integration methods for solutes 604 in grab samples of runoff water, as compared to flow-proportional sampling. Journal of 605 Hydrology 319, 266-281.

606 Schulz, R., 2001a. Rainfall-induced sediment and pesticide input from orchards into the 607 Lourens River, Western Cape, South Africa: importance of a single event. Water Research 35, 608 1869-1876.

609 Schulz, R., 2001b. Comparison of spreaydrift- and runoff-related input of azinphos-methyl 610 and endosulfan from fruit onchards into the Lourens River, South Africa. Chemosphere 45, $611543-551$.

612 Taillandier, P., 2008. Data treatment and study of the hydrological mechanism of the 613 Morcille's catchment area (In French). Rapport de stage, Institut Polytechnique de Grenoble, 614 Ecole d'ingénieurs pour l'énergie, l'eau et l'environnement, 85 pp.

615 Tomlin, C.D.S., 2000. The Pesticide Manual, twelfth ed. British Crop Protection Council, 616 Farnham, UK.

617 Vryzas, Z., Vassiliou, G., Alexoudis, C., Papadopoulou-Mourkidou, E., 2009. Spatial and 618 temporal distribution of pesticide residues in surface waters in northeastern Greece. Water 619 research 43, 1-10.

620 Zonta, R., Collavini, F., Zaggia, L., Zuliani, A., 2005. The effect of floods on the transport of 621 suspended sediments and contaminants: A case study from the estuary of the Dese River 622 (Venice Lagoon, Italy), Environment 31, 948-958. 


\section{Figures captions}

625 Figure 1. Location of the Morcille watershed and the sampling sites.

626 Figure 2. Land use at the three sampling sites on the Morcille watershed.

627 Figure 3. Study of pesticide stability during storage in PE bottles over a seven days period. Y628 axis is the ratio expressed in percent of the concentration of pesticide at time $t(C)$ over the 629 concentration at t0 $(\mathrm{C} 0)$.

630 Figure 4. Daily rainfall $(\mathrm{mm})$ and water flow $(\mathrm{L} / \mathrm{s})$ at site 2 in the Morcille catchment from 631 March 2007 to March 2008.

632 Figure 5. Pesticides concentrations (in $\mu \mathrm{g} / \mathrm{L}$ ) along the Morcilles stream from March 2007 to 633 March 2008; a: Diuron and DCPMU; b: Total fungicide (sum of the five fungicides 634 monitored).

635 Figure 6. Water flow $\left(\mathrm{m}^{3} / \mathrm{s}\right)$ versus total pesticide concentrations $(\mu \mathrm{g} / \mathrm{L})$ in the Morcille stream 636 at site 2 during weekly monitoring (March 2007 to September 2007).

637 Figure 7. Dissolved pesticide concentrations $(\mu \mathrm{g} / \mathrm{L})$ at site 2 from March 2007 to March 2008.

638 Figure 8. Diuron concentrations $(\mu \mathrm{g} / \mathrm{L})$ and water flow $\left(\mathrm{m}^{3} / \mathrm{s}\right)$ at site 2 during flood events for 639 the April-September 2007 period.

640 Figure 9. Water flow $\left(\mathrm{m}^{3} / \mathrm{s}\right)$ in the Morcille stream at site 2, with the sampling dates for the 641 monitoring of grab samples and floods in August $2007(\times$ : diuron concentration measured 642 using grab sampling).

643 Figure 10. Diuron flux (g) versus water volumes $\left(\mathrm{m}^{3}\right)$ during 7 floods (site 2).

644 Figure 11. Monthly diuron flux (g) at site 2 in August 2007, estimated using different 645 methods and monitoring data. 


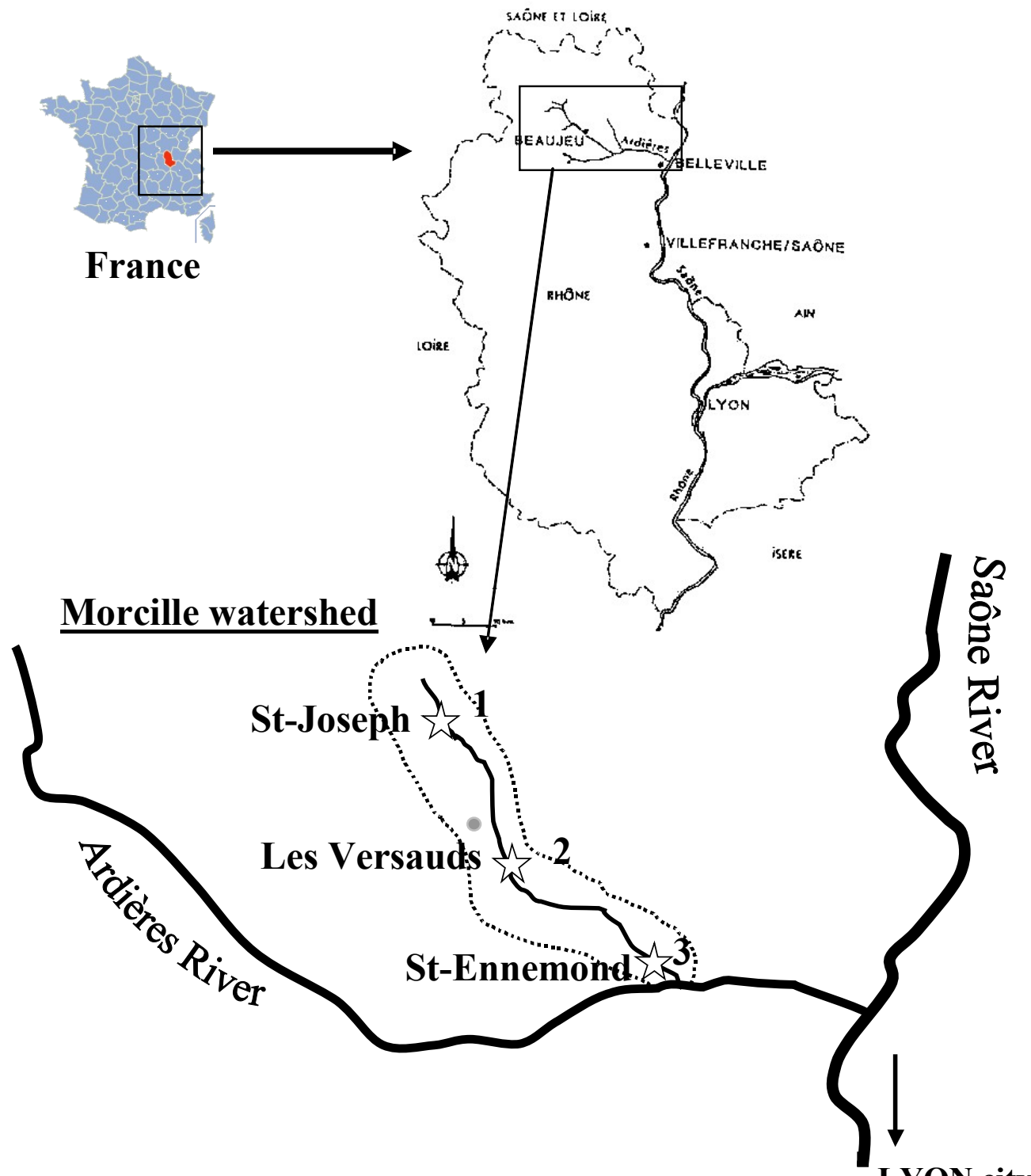

646

647 Figure 1. Location of the Morcille watershed and the sampling sites. 
661

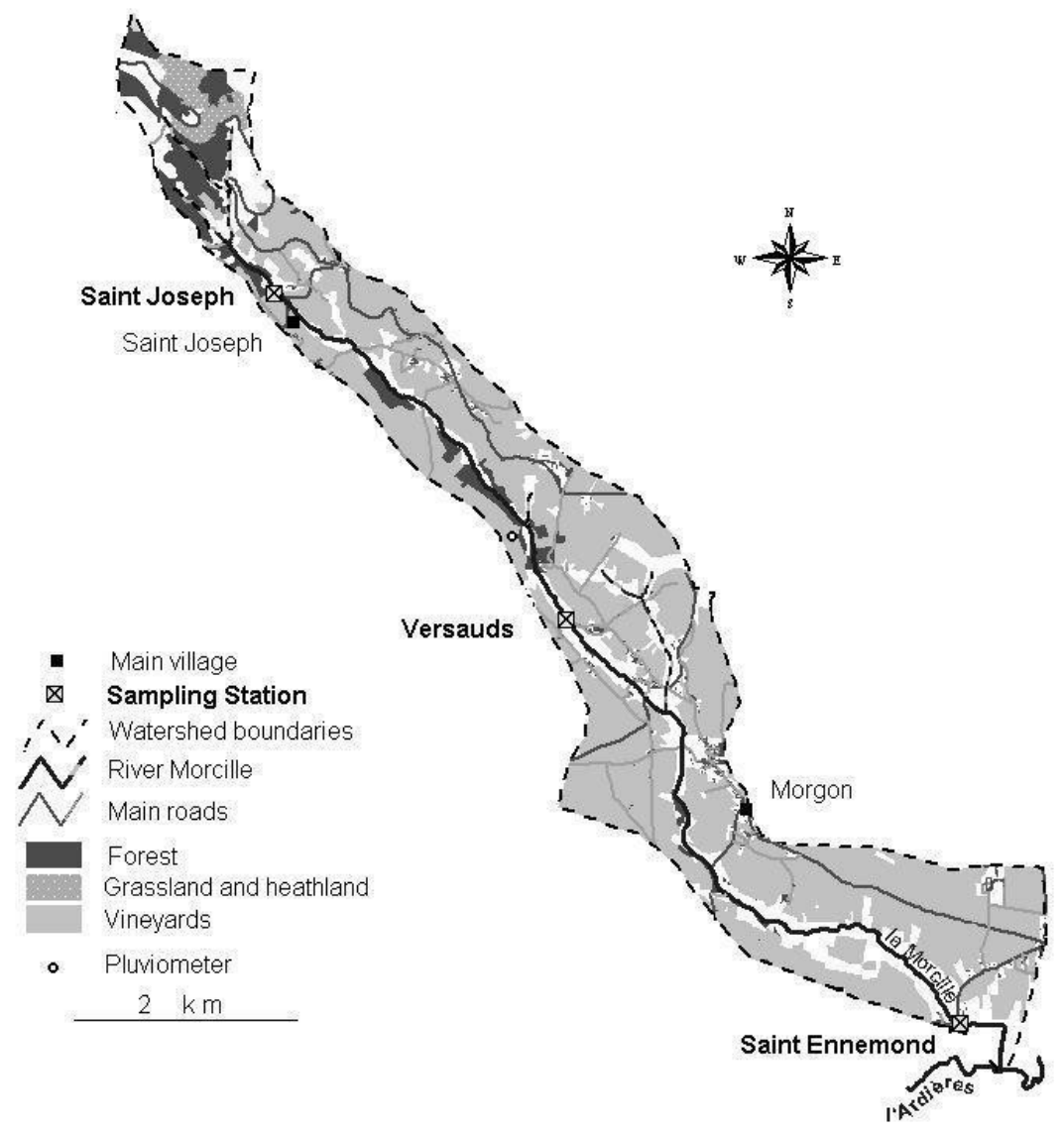

662

663

$664 \square$ Industrial and urban

665

666

Vineyard

$667 \square$ Forest

668

669

Cultures

670

671

Grasslands and heathlands

672

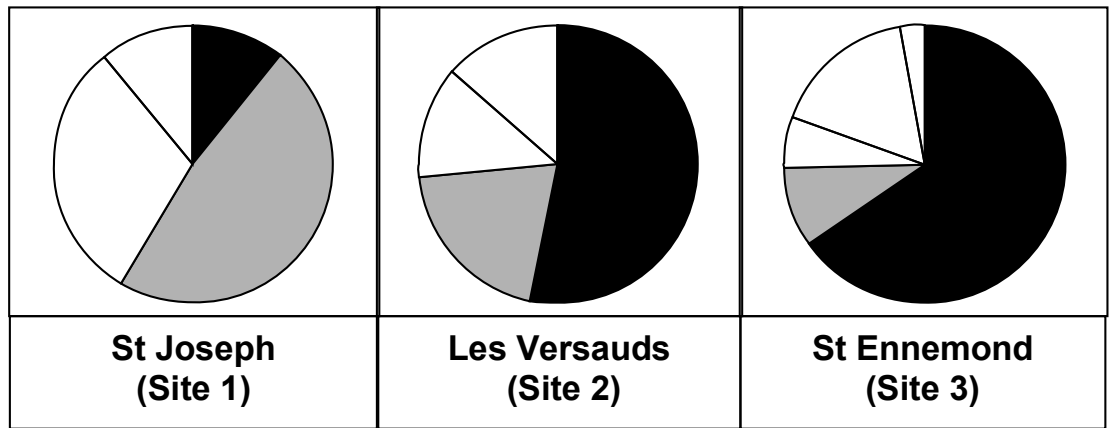

673Figure 2. Land use at the three sampling sites on the Morcille watershed.

674

675 


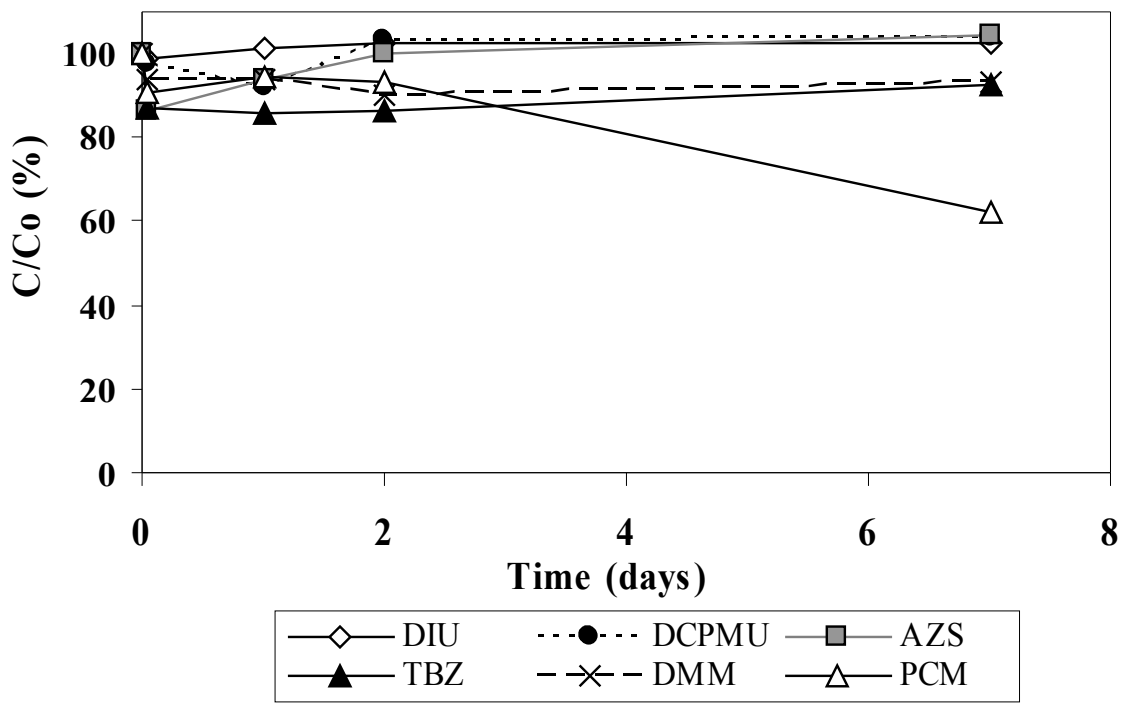

677 Figure 3. Study of pesticide stability during storage in PE bottles over a seven days period.

$678 \mathrm{Y}$-axis is the ratio expressed in percent of the concentration of pesticide at time $\mathrm{t}(\mathrm{C})$ over the 679 concentration at $\mathrm{t} 0(\mathrm{C} 0)$.

680

681

682

683

684 


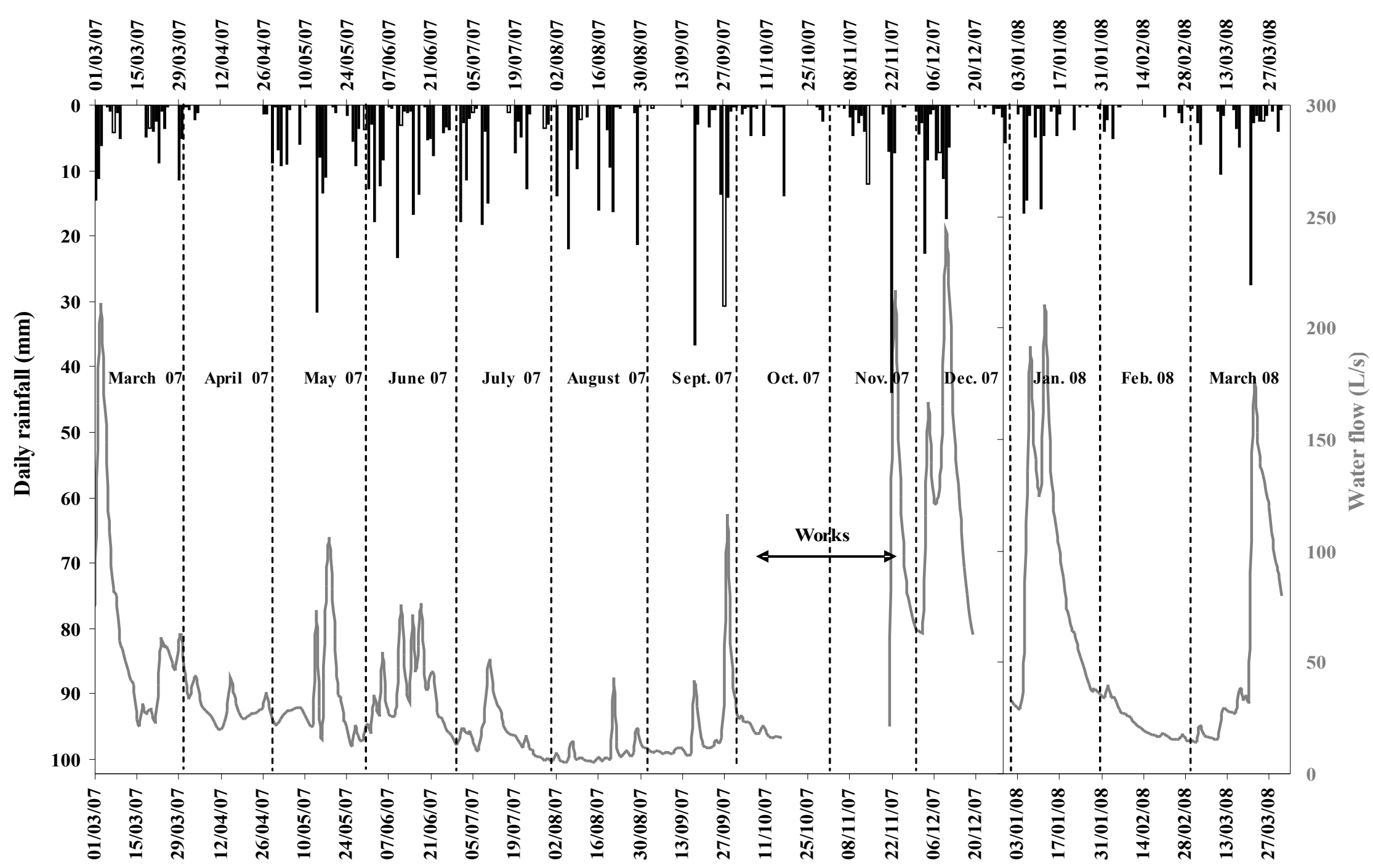

686 Figure 4. Daily rainfall (mm) and water flow (L/s) at site 2 in the Morcille catchment from March 2007 to March 2008. 


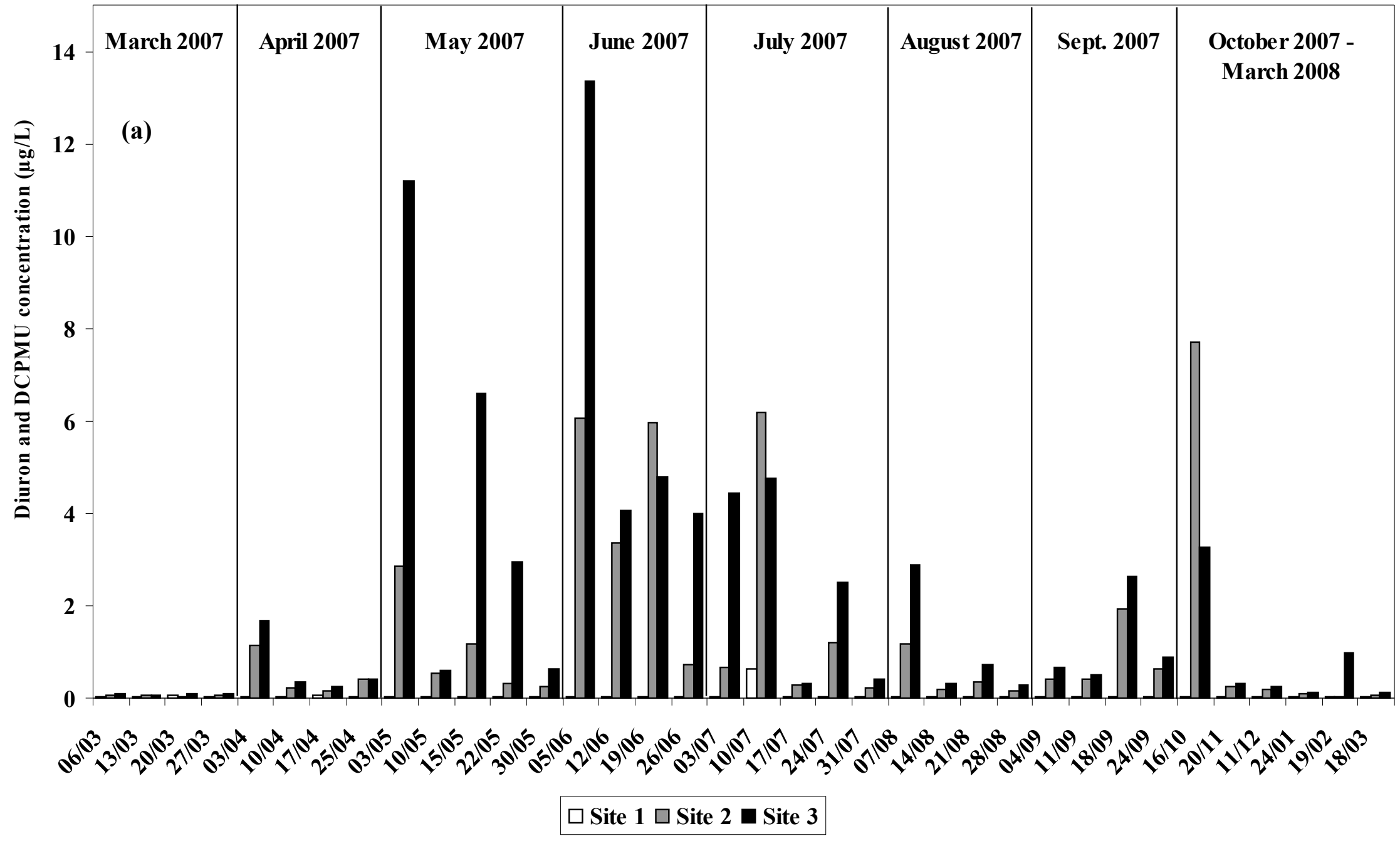




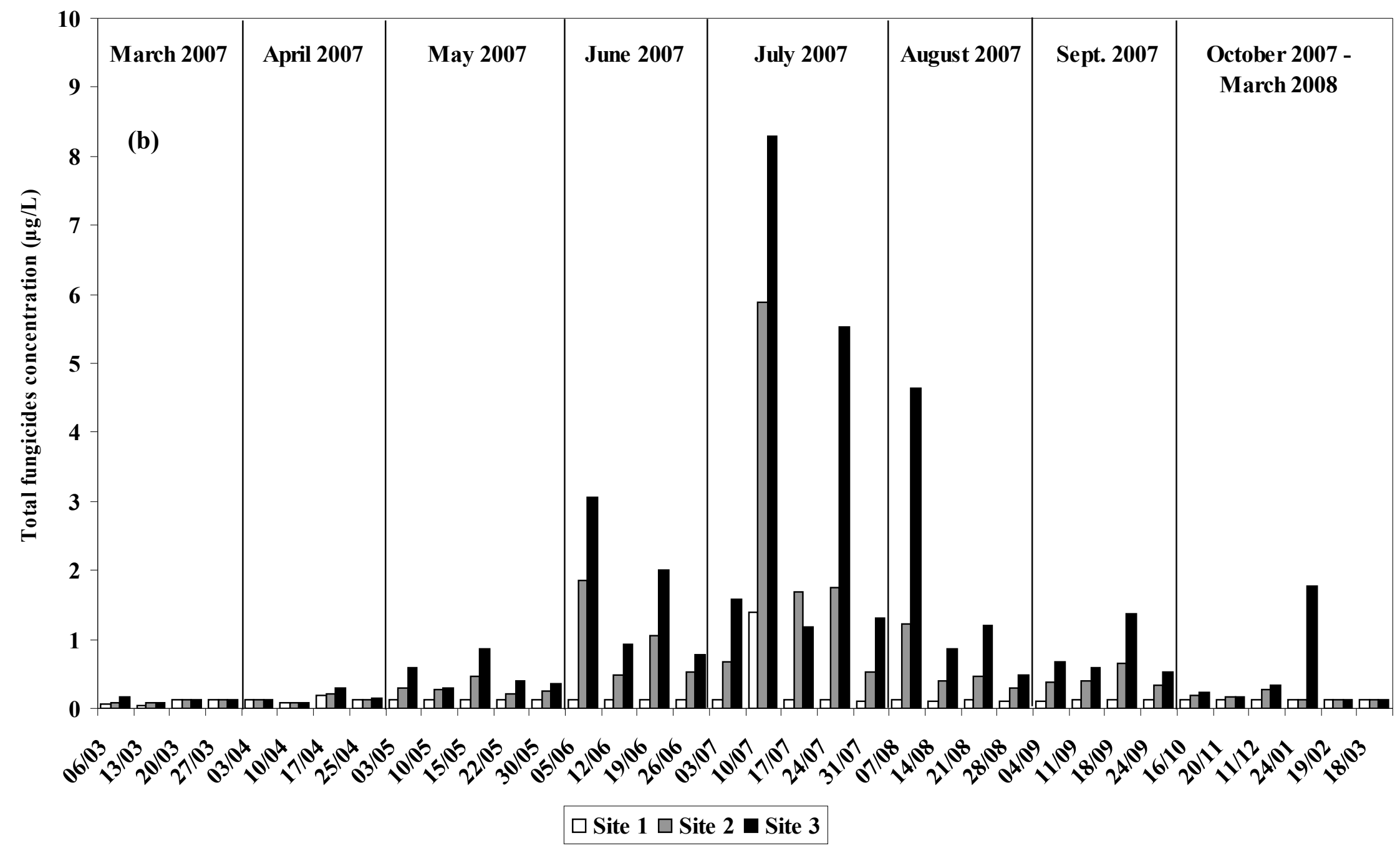

690

691 Figure 5. Pesticides concentrations (in $\mu \mathrm{g} / \mathrm{L}$ ) along the Morcille stream from March 2007 to March 2008; a: Diuron and DCPMU; b: Total 692 fungicide (sum of the five fungicides monitored). 


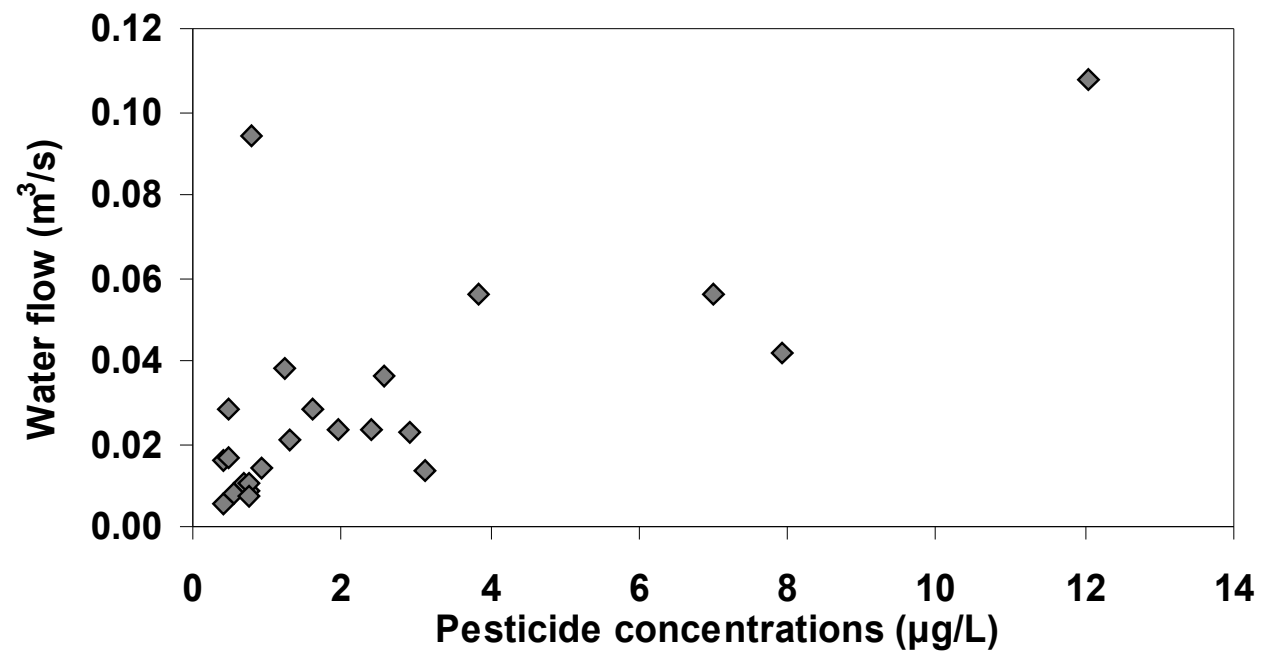

694 Figure 6. Water flow $\left(\mathrm{m}^{3} / \mathrm{s}\right)$ versus total pesticide concentrations $(\mu \mathrm{g} / \mathrm{L})$ in the Morcille 695 stream at site 2 during weekly monitoring (March 2007 to September 2007).

696 


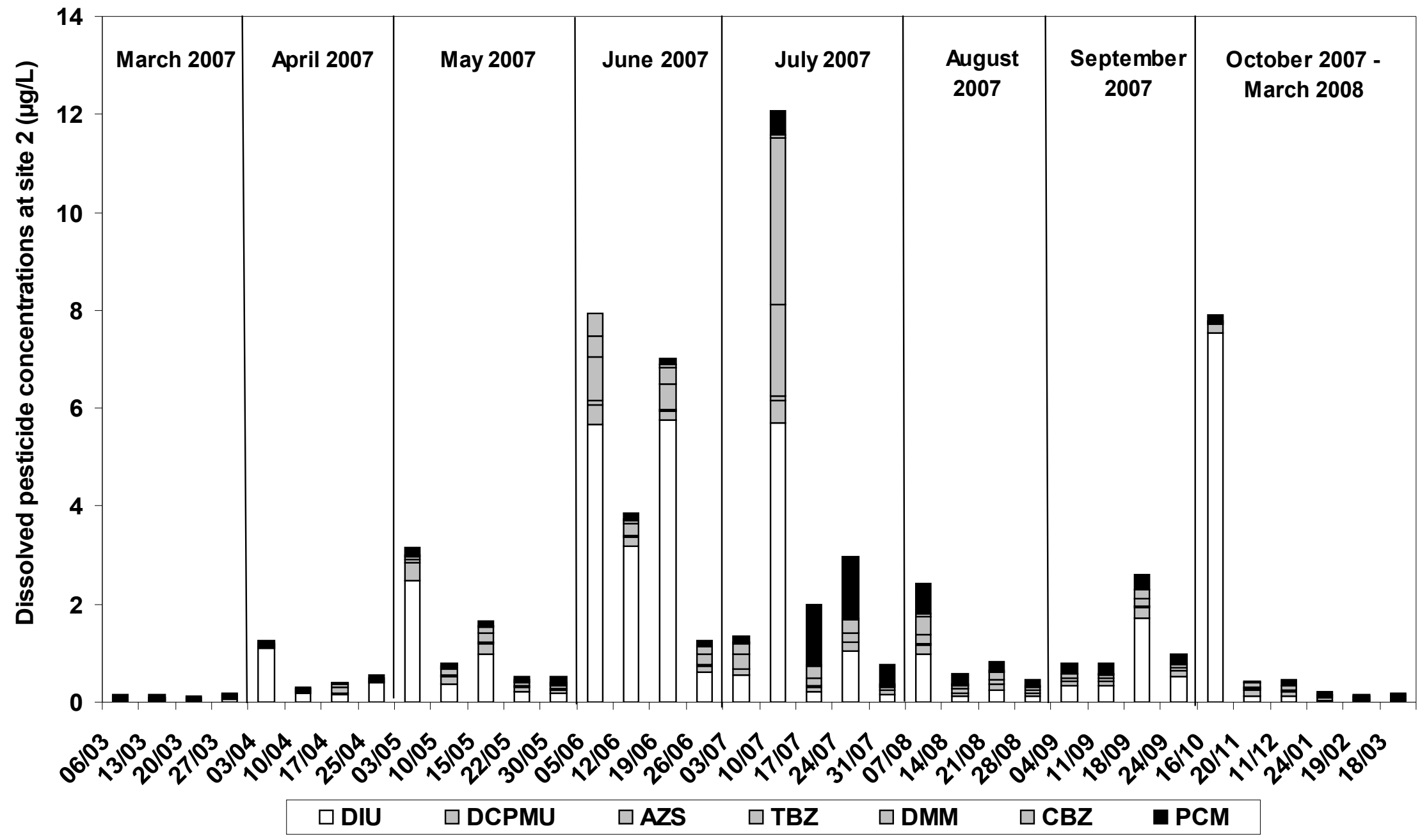

697

698 Figure 7. Dissolved pesticide concentrations ( $\mu \mathrm{g} / \mathrm{L})$ at site 2 from March 2007 to March 2008. 

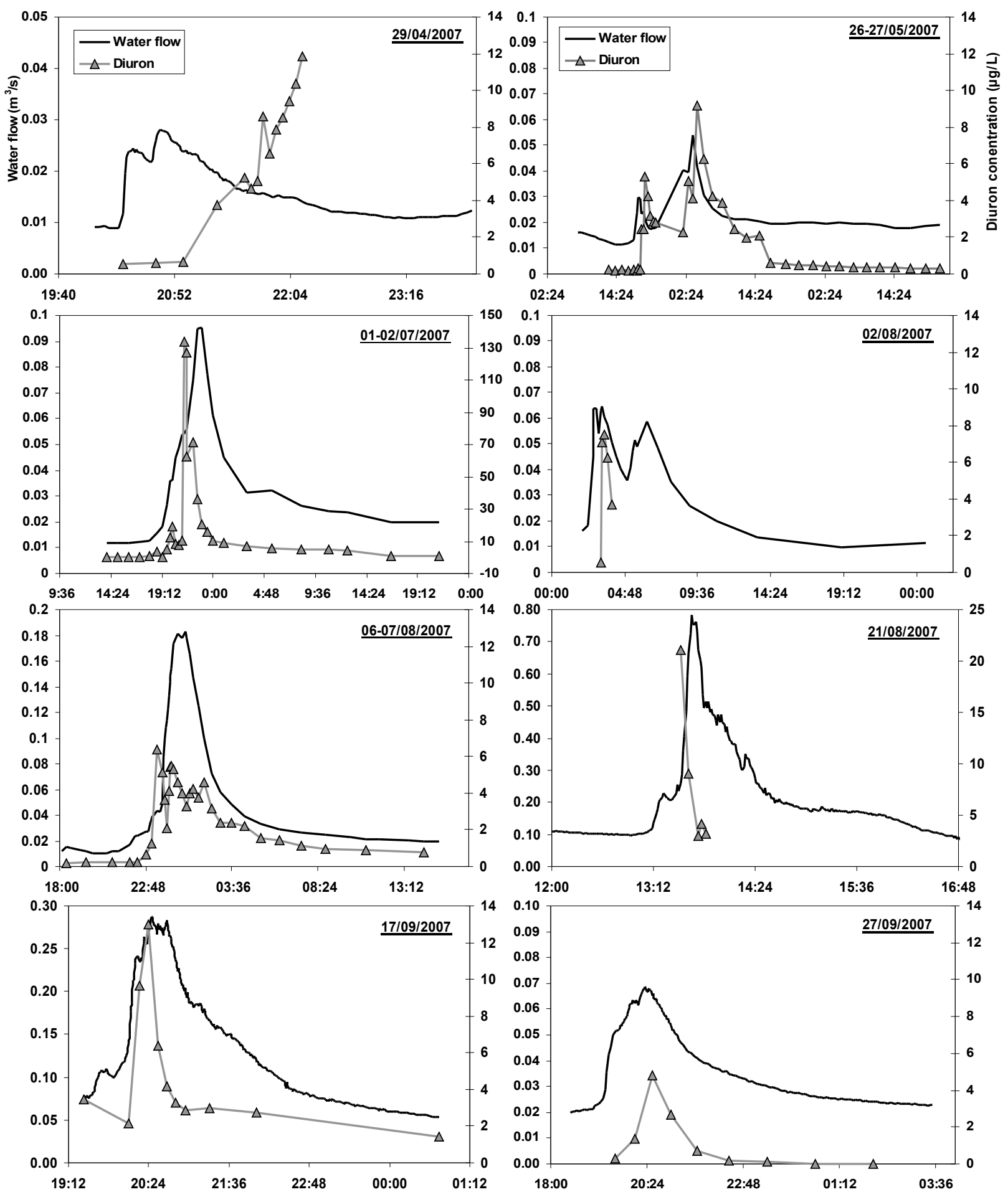

700 Figure 8. Diuron concentrations $(\mu \mathrm{g} / \mathrm{L})$ and water flow $\left(\mathrm{m}^{3} / \mathrm{s}\right)$ at site 2 during flood events

701 for the April-September 2007 period. 


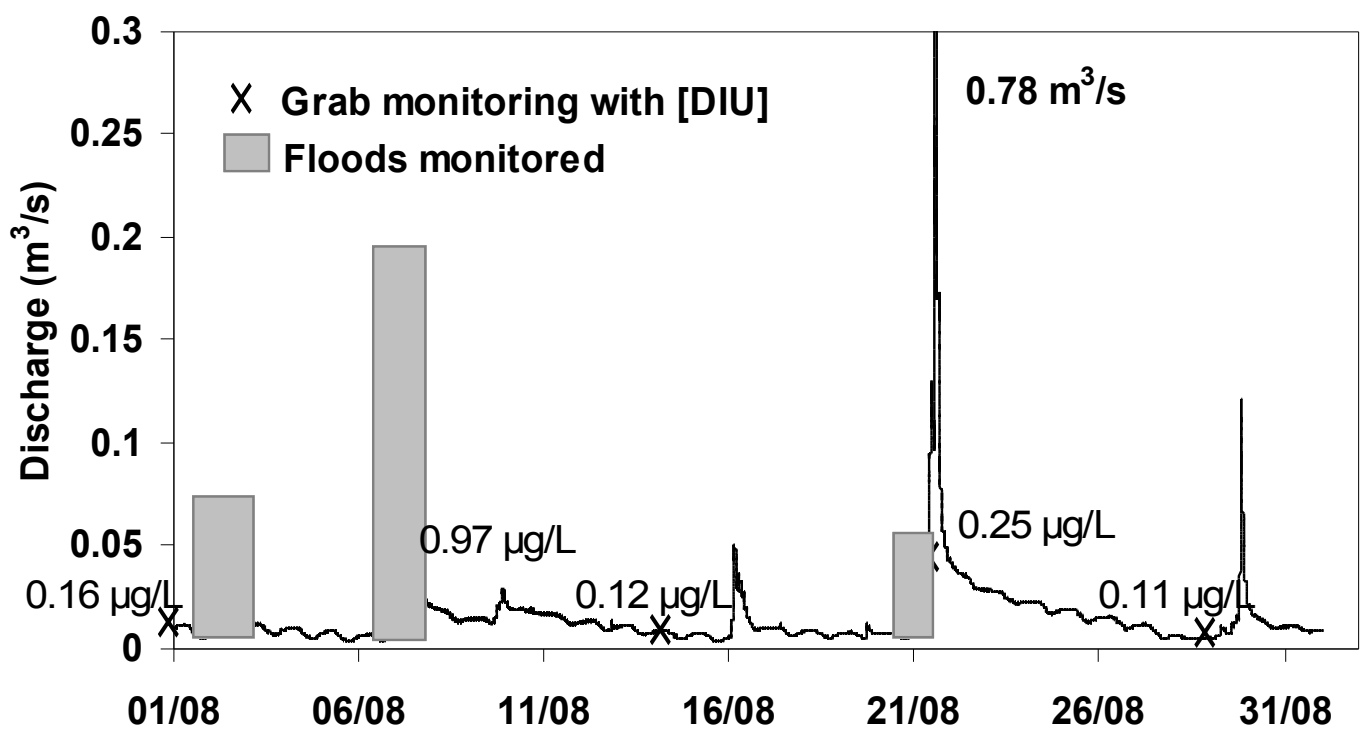

708 Figure 9. Water flow $\left(\mathrm{m}^{3} / \mathrm{s}\right)$ in the Morcille stream at site 2, with the sampling dates for the 709 monitoring of grab samples and floods in August $2007(\times$ : diuron concentration measured 710 using grab sampling). 


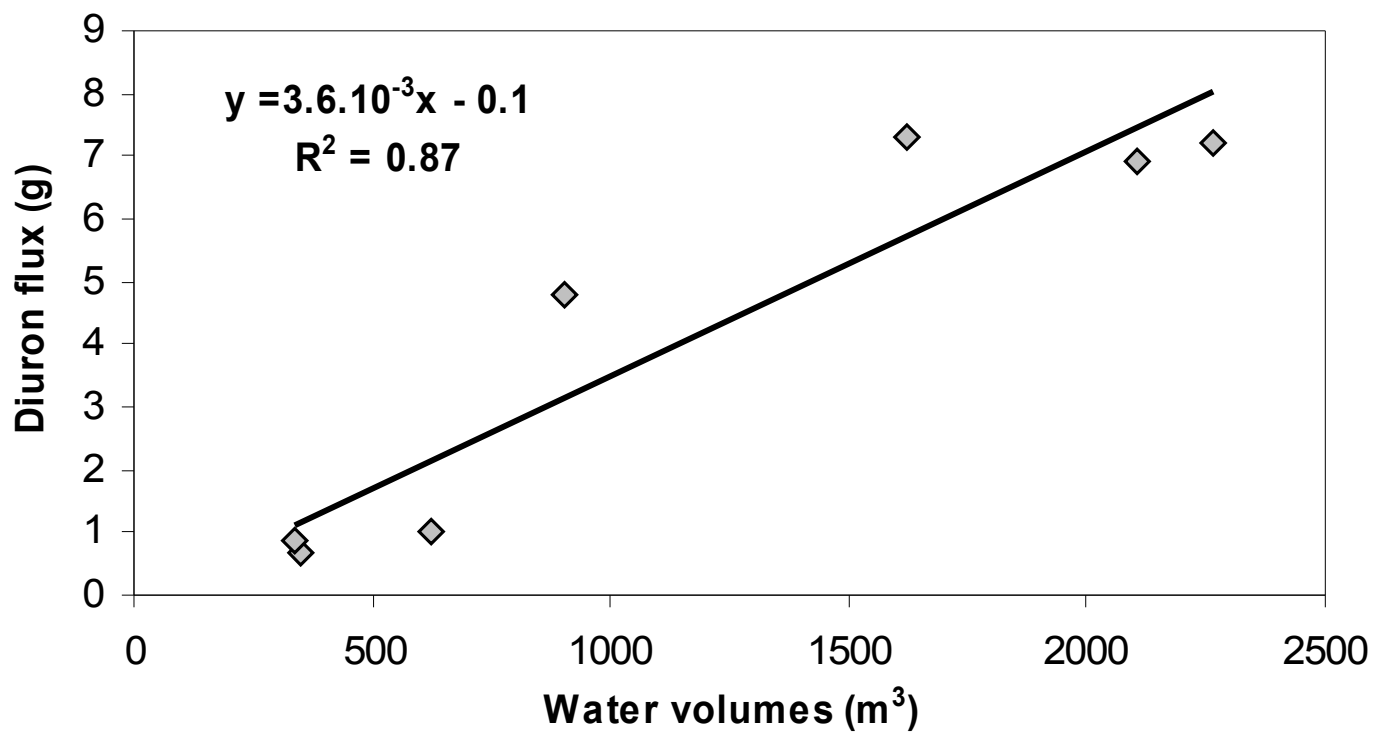

738 Figure 10. Diuron flux (g) versus water volumes $\left(\mathrm{m}^{3}\right)$ during 7 floods (site 2). 
771

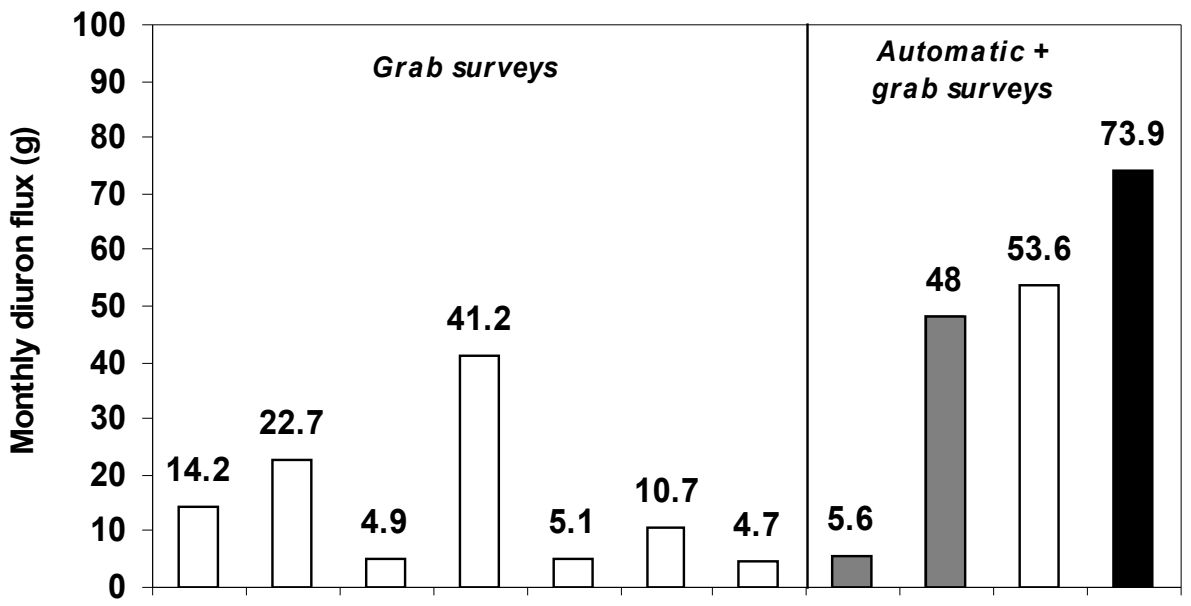

772

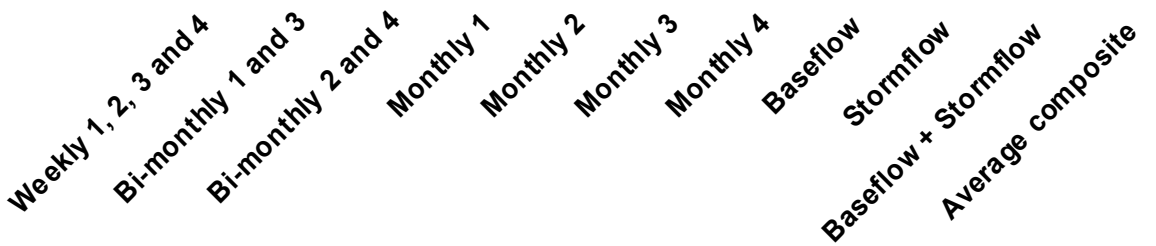

773 Figure 11. Monthly diuron flux (g) at site 2 in August 2007, estimated using different 774 methods and monitoring data. 
776 Table 1. Properties of the studied pesticides (Tomlin, 2000; AFSSA, 2008).

\begin{tabular}{|clcccc|}
\hline Compound (abbreviation) & Category & Water solubility (mg/L) & Koc (L/kg) & $\begin{array}{c}\text { Log } \\
\text { Kow }\end{array}$ & $\begin{array}{c}\text { Half life } \\
\text { (days) }\end{array}$ \\
\hline Azoxystrobin (AZS) & Fungicide & 6.0 & 423 & 2.50 & $8.7-14$ \\
Carbendazim (CBZ) & Fungicide & 8.0 & 200 & 1.56 & $30-150$ \\
Dimetomorph (DMM) & Fungicide & 18.0 & $290-566$ & 2.70 & $23-35$ \\
Diuron (DIU) & Herbicide & 36.4 & 480 & 2.85 & $90-180$ \\
Procymidone (PCM) & Fungicide & 4.5 & 1514 & 3.14 & $28-84$ \\
Tebuconazole (TBZ) & Fungicide & 32.0 & $803-1251$ & 3.70 & $43-170$ \\
\hline
\end{tabular}

777

778 Tableau 2. Annual pesticide fluxes in $\mathrm{g}$ and $\mathrm{g} / \mathrm{Ha}$ and percentage of exportation in the Morcille stream 779

\begin{tabular}{|c|c|c|c|c|}
\hline Pesticides & $\begin{array}{c}\text { Annual } \\
\text { flux(g) }\end{array}$ & $\begin{array}{c}\text { Annual specific flux } \\
\text { (g/Ha) }\end{array}$ & $\begin{array}{c}\text { Annual recommended amount (g/Ha) } \\
\text { (Couteux and Lejeune, 2007) }\end{array}$ & $\begin{array}{c}\text { Percentage of } \\
\text { exportation (\%) }\end{array}$ \\
\hline DIU & 1335 & 7.60 & 1500 & 0.57 \\
DCPMU & 167.7 & 0.96 & - & 0.07 \\
AZS & 31.7 & 0.18 & 250 & 1.80 \\
TBZ & 223.8 & 1.28 & 70 & 0.38 \\
DMM & 164.0 & 0.94 & 250 & 0.28 \\
CBZ & 52.0 & 0.30 & 105 & 0.14 \\
PCM & 180.0 & 1.03 & 750 & \\
\hline Total & $\mathbf{2 1 5 4}$ & $\mathbf{1 2 . 3 0}$ & & \\
\hline
\end{tabular}

780

781 Tableau 3. Maximal pesticide concentrations $(\mu \mathrm{g} / \mathrm{L})$ and fluxes $(\mathrm{g})$ for each monitored flood at site 2.

\begin{tabular}{|c|c|c|c|c|c|c|c|c|}
\hline & & DIU & DCPMU & AZS & TBZ & DMM & CBZ & PCM \\
\hline \multirow{2}{*}{ 29/04/2007 } & $\operatorname{Cmax}(\mu \mathrm{g} / \mathrm{L})$ & 11.9 & 1.09 & 0.13 & 0.60 & 0.10 & 0.10 & 0.27 \\
\hline & Flux (g) & 0.477 & 0.023 & 0.0008 & 0.011 & 0.079 & 0.0005 & 0.027 \\
\hline \multirow{2}{*}{$26 / 05 / 2007$} & $\mathrm{Cmax}(\mu \mathrm{g} / \mathrm{L})$ & 5.30 & 0.30 & 0.43 & 0.32 & 0.75 & 0.10 & 0.14 \\
\hline & Flux $(\mathrm{g})$ & 0.68 & 0.064 & 0.057 & 0.057 & 0.084 & 0.015 & 0.040 \\
\hline \multirow{2}{*}{$\begin{array}{c}27- \\
28 / 05 / 2007\end{array}$} & $\mathrm{Cmax}(\mu \mathrm{g} / \mathrm{L})$ & 9.20 & 0.60 & 0.54 & 1.01 & 0.82 & 0.12 & 0.23 \\
\hline & Flux $(\mathrm{g})$ & 6.91 & 0.59 & 0.46 & 1.02 & 0.55 & 0.13 & 0.26 \\
\hline \multirow{2}{*}{$\begin{array}{c}01- \\
02 / 07 / 2007 \\
\end{array}$} & $\operatorname{Cmax}(\mu \mathrm{g} / \mathrm{L})$ & 134.0 & 0.71 & 0.14 & 6.50 & 14.4 & 0.16 & 1.30 \\
\hline & Flux $(\mathrm{g})$ & 45.5 & 0.98 & 0.14 & 5.00 & 6.80 & 0.24 & 1.50 \\
\hline \multirow{2}{*}{$02 / 08 / 2007$} & $\mathrm{Cmax}(\mu \mathrm{g} / \mathrm{L})$ & 7.50 & - & - & - & - & - & - \\
\hline & Flux (g) & 0.89 & - & - & - & - & - & - \\
\hline \multirow{2}{*}{$\begin{array}{c}\text { 06- } \\
\text { 07/08/2007 } \\
\end{array}$} & $\mathrm{Cmax}(\mu \mathrm{g} / \mathrm{L})$ & 6.40 & 0.79 & 0.08 & 1.41 & 2.81 & 0.28 & 3.17 \\
\hline & Flux (g) & 7.21 & 1.08 & 0.082 & 1.50 & 3.67 & 0.28 & 3.49 \\
\hline \multirow{2}{*}{$21 / 08 / 2007$} & $\operatorname{Cmax}(\mu \mathrm{g} / \mathrm{L})$ & 21.1 & - & - & - & 5.98 & - & - \\
\hline & Flux $(\mathrm{g})$ & 4.80 & - & - & - & 1.3 & - & - \\
\hline \multirow{2}{*}{$17 / 09 / 2007$} & $\operatorname{Cmax}(\mu \mathrm{g} / \mathrm{L})$ & 13.0 & - & - & - & - & - & 1.40 \\
\hline & Flux (g) & 7.33 & - & - & - & - & - & 0.193 \\
\hline \multirow{2}{*}{ 27/09/2007 } & $\operatorname{Cmax}(\mu \mathrm{g} / \mathrm{L})$ & 4.80 & - & - & - & - & - & - \\
\hline & Flux $(\mathrm{g})$ & 1.01 & - & - & - & - & - & - \\
\hline
\end{tabular}

782

783

784

785

786

787

788

789

790

791

792 
793 Table 4. Comparaison of calculated and estimated diuron flux (g) during floods at site 2.

\begin{tabular}{|c|c|c|c|c|}
\hline Flood eve & $\begin{array}{c}\text { Calculated } \\
\text { diuron flux } \mathbf{( g )}\end{array}$ & $\begin{array}{c}\text { Water volumes } \\
\mathbf{( m}^{\mathbf{3}} \mathbf{)}\end{array}$ & $\begin{array}{c}\text { Estimated } \\
\text { diuron flux (g) }\end{array}$ & Bias (\%) \\
\hline 26 May 2007 & 0.68 & 348 & 0.80 & 13 \\
27-28 May 2007 & 6.91 & 2106 & 7.1 & 3 \\
02 August 2007 & 0.89 & 335 & 0.70 & -19 \\
06-07 August 2007 & 7.21 & 2263 & 7.70 & 6 \\
21 August 2007 & 5.88 & 1970 & 6.60 & 12 \\
17 September 2007 & 7.33 & 1619 & 5.30 & -27 \\
27 September 2007 & 1.01 & 621 & 1.70 & 73 \\
\hline
\end{tabular}

794

795

796 